\title{
Exploring the phytoplasmas, plant pathogenic bacteria
}

\author{
Kensaku Maejima $\cdot$ Kenro Oshima \\ Shigetou Namba
}

Received: 3 September 2013/Accepted: 11 December 2013/Published online: 18 March 2014

(C) The Author(s) 2014. This article is published with open access at Springerlink.com

\begin{abstract}
Phytoplasmas are plant pathogenic bacteria associated with devastating damage to over 700 plant species worldwide. It is agriculturally important to identify factors involved in their pathogenicity and to discover effective measures to control phytoplasma diseases. Despite their economic importance, phytoplasmas remain the most poorly characterized plant pathogens, primarily because efforts at in vitro culture, gene delivery, and mutagenesis have been unsuccessful. However, recent molecular studies have revealed unique biological features of phytoplasmas. This review summarizes the history and recent progress in phytoplasma research, focusing on (1) the discovery of phytoplasmas, (2) molecular classification of phytoplasmas, (3) diagnosis of phytoplasma diseases, (4) reductive evolution of the genomes, (5) characteristic features of the plasmids, (6) molecular mechanisms of insect transmissibility, and (7) virulence factors involved in their unique symptoms.
\end{abstract}

Keywords Diagnosis - Genome - Phytoplasma - Insect transmission - Molecular classification · Virulence factors

\section{Introduction}

Phytoplasmas are plant pathogenic bacteria in the class Mollicutes and are formally called mycoplasma-like organisms (MLOs) (Doi et al. 1967). They are transmitted

\footnotetext{
K. Maejima $\cdot$ K. Oshima $\cdot$ S. Namba $(\square)$

Department of Agricultural and Environmental Biology,

Graduate School of Agricultural and Life Sciences,

The University of Tokyo, 1-1-1 Yayoi, Bunkyo-ku,

Tokyo 113-8657, Japan

e-mail: anamba@mail.ecc.u-tokyo.ac.jp
}

by insect vectors (leafhoppers, planthoppers, and psyllids) and infect hundreds of plant species worldwide, including many economically important crops, fruit trees, and ornamental plants (Hogenhout et al. 2008; Oshima et al. 2013). Infected plants show a wide range of symptoms including stunting, yellowing, witches' broom (development of numerous tiny shoot branches with small leaves), phyllody (formation of leaf-like tissues instead of flowers), virescence (greening of floral organs), proliferation (growth of shoots from floral organs), purple top (reddening of leaves and stems), and phloem necrosis (Fig. 1). Phytoplasma infection is often fatal and causes devastating damage to global agricultural production. Due not only to difficulties in culturing phytoplasmas in vitro and in manipulating them genetically but also to their recalcitrant biological properties such as restriction to phloem cells, nontransmissibility by manual inoculation, and high vector specificity, these organisms are one of the most poorly characterized groups of plant pathogens. However, recent molecular studies have revealed interesting features of phytoplasmas. This review summarizes the history and recent progress in phytoplasma research, especially in Japan.

\section{Phytoplasmal diseases and discovery of the pathogen}

Phytoplasmal diseases have been observed globally. In Japan, mulberry dwarf disease has caused severe damage to mulberry plants, the sole source of food for silkworms, since the Tokugawa period (1603-1868) (Okuda 1972). In 1890, Shirai (the first president of the Phytopathological Society of Japan and the first professor of plant pathology at the University of Tokyo) reported that this disease was transmissible by grafting, although the causal agent remained unknown (Shirai 1890). Since the early twentieth 


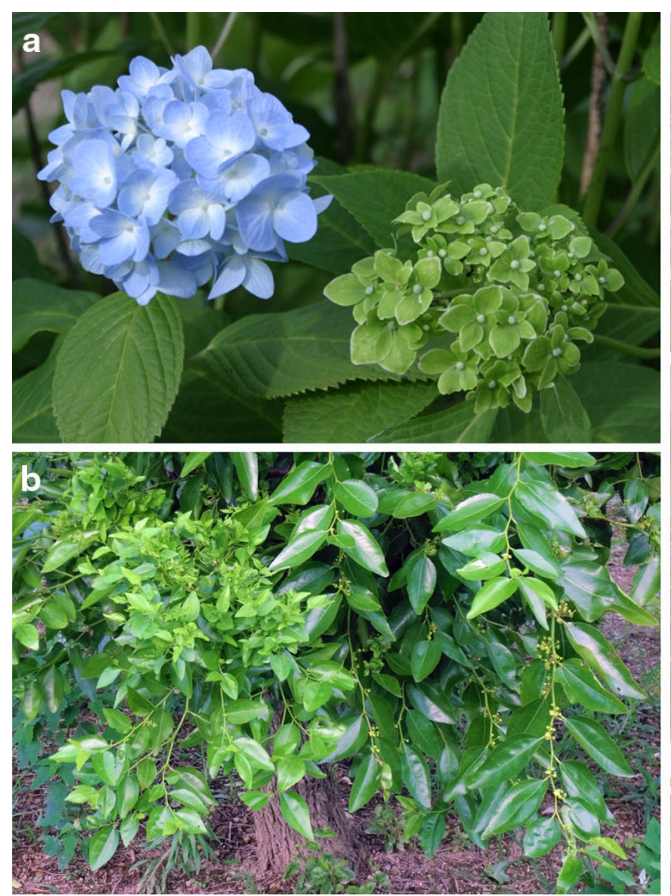

Fig. 1 Unique symptoms caused by phytoplasma infection. a Phyllody symptoms on hydrangea induced by infection with 'Candidatus Phytoplasma japonicum' JHP phytoplasma (right). b Witches' broom symptoms on Ziziphus jujuba induced by infection with ' $\mathrm{Ca}$. P.

century, other phytoplasmal diseases, including paulownia witches' broom disease (Kawakami 1902) and rice yellow dwarf disease (Anonymous 1919) in Japan, as well as aster yellows disease (Kunkel 1926) in the United States, have been reported. These diseases were initially attributed to plant viruses because of their insect transmissibility and virus-like symptoms. However, Doi et al. (1967) discovered small pleomorphic bodies that resembled mycoplasmas (bacterial pathogens of humans and animals) in ultrathin sections of the phloem of plants affected by diseases such as mulberry dwarf, paulownia witches' broom, and aster yellows. The associated agents were named mycoplasma-like organisms (MLOs) because of their morphological similarity to mycoplasmas, as well as their sensitivity to tetracycline antibiotics (Ishiie et al. 1967). Discovery of these novel plant pathogens, MLOs, was confirmed in subsequent studies (Granados et al. 1968; Hull et al. 1969).

\section{Molecular classification of phytoplasmas}

More than four decades since their discovery, MLOs remain the most poorly characterized phytopathogens from every viewpoint, including biology and taxonomy, because they are difficult to culture in vitro. Moreover, since classification of MLOs was not possible, each MLO was named

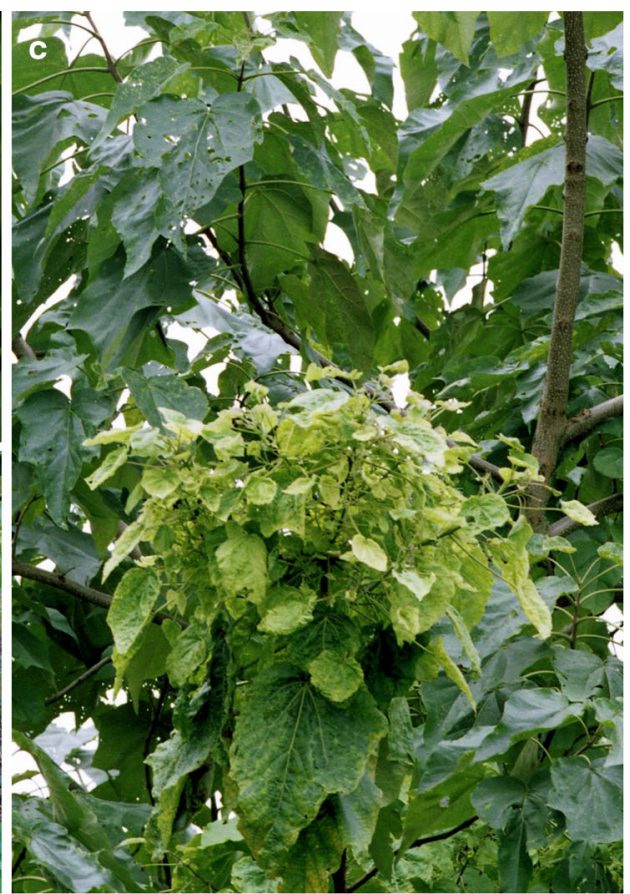

ziziphi' (left). c Witches' broom symptoms on Paulownia tomentosa induced by infection with ' $\mathrm{Ca}$. P. asteris' (left). Photo courtesy of Dr. Norio Nishimura (Koibuchi College of Agriculture and Nutrition)

based on its natural host and symptoms. According to this nomenclature, as of the late 1980s, several hundred MLOs had been reported globally, and 63 MLOs were reported in Japan (Kishi 1987). In the early 1990s, the 16S rRNA gene sequences of MLOs were compared with each other, as well as with Acholeplasma laidlawii, Spiroplasma citri, and several mycoplasmas (Kuske and Kirkpatrick 1992; Namba et al. 1993b). These analyses revealed that MLOs were a monophyletic group within the class Mollicutes, but were more closely related to Acholeplasma spp. than to Spiroplasma spp. and animal mycoplasmas. In 1994, the name "phytoplasmas" was adopted by the Phytoplasma Working Team at the 10th Congress of the International Organization of Mycoplasmology to collectively denote MLOs. In 2004, phytoplasmas were proposed to be within a novel genus 'Candidatus Phytoplasma' (IRPCM 2004). Approximately 40 phytoplasmal species have been reported worldwide (Hogenhout et al. 2008; Jung et al. 2002, 2003b, c; Sawayanagi et al. 1999). In Japan, approximately 70 strains of phytoplasmas (PSJ NIAS 2012) have been reclassified into nine species (Fig. 2).

\section{Diagnosis of phytoplasma diseases}

Phytoplasmas cause devastating damage to many plant species worldwide. For example, in 2001, a phytoplasma 


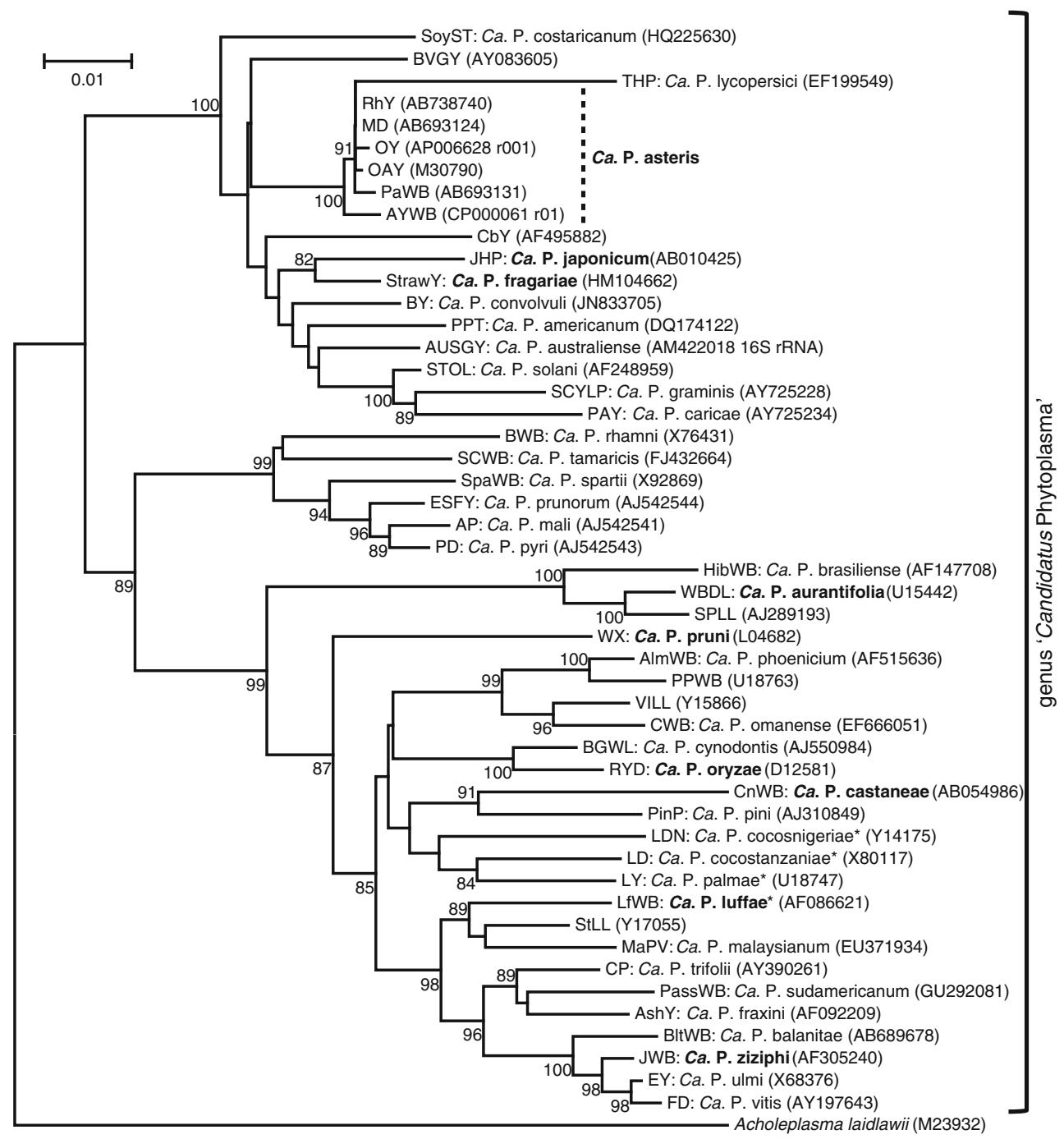

Fig. 2 Phylogenetic relationship of phytoplasmas. A phylogenetic tree was constructed using the neighbor-joining method (Saitou and Nei 1987) with 16S rRNA gene sequences from phytoplasmas and acholeplasma (outgroup). Numbers on the branches are the bootstrap values (only values $>80 \%$ are shown). GenBank accession numbers are in parentheses. Asterisks indicate the proposed provisional names (IRPCM 2004). Scale bar indicates the number of nucleotide substitutions per site. Species found in Japan are in bold type. $A \operatorname{lm} W B$ almond witches' broom, $A P$ apple proliferation, Ash $Y$ ash yellows, AUSGY Australian grapevine yellows, $A Y-W B$ aster yellows phytoplasma strain witches' broom, $B G W L$ Bermuda grass white leaf, BltWB Balanites triflora witches' broom, $B V G Y$ Buckland Valley grapevine yellows, $B W B$ buckthorn witches' broom, $B Y$ bindweed yellows, $C a$. $P$. Candidatus Phytoplasma, $C b Y$ chinaberry yellows, $C n W B$ chestnut witches' broom, $C P$ clover proliferation, $C W B$ cassia witches' broom, $E S F Y$ European stone fruit yellows, $E Y$ elm yellows,

outbreak in apple trees caused losses of about $€ 100$ million in Italy and $€ 25$ million in Germany (Strauss 2009). Lethal yellowing of palm has killed millions of coconut palm trees in the Caribbean over the past 40 years (Brown et al. 2006). In Japan, phytoplasmas also cause serious economic losses to agricultural production.
$F D$ flavescence dorée of grapevine, $H i b W B$ hibiscus witches' broom, $J H P$ Japanese hydrangea phyllody, $J W B$ jujube witches' broom, $L D$ coconut lethal yellowing, substrain Tanzanian lethal disease, $L D N$ coconut lethal yellowing, substrain Nigerian Awka disease, $L Y$ coconut lethal yellowing, LfWB loofah witches' broom, MaPV Malaysian periwinkle virescence, $M D$ mulberry dwarf, $O A Y$ oenothera aster yellows, $O Y$ onion yellows, Pass WB passion fruit witches' broom, $P a W B$ paulownia witches' broom, $P A Y$ papaya, $P D$ pear decline, $P$ in $P$ pine phytoplasma, $P P T$ potato purple top wilt, $P P W B$ Caribbean pigeon pea witches' broom, $R h Y$ rhus yellows, $R Y D$ rice yellow dwarf, SCWB salt cedar witches' broom, SCYLP sugarcane yellow leaf syndrome, SoyST soybean stunt, SpaWB spartium witches' broom, SPLL sweet potato little leaf, STOL stolbur, StrawY strawberry yellows, THP 'Hoja de perejil' (parsley leaf) of tomato, $V i L L$ vigna little leaf, $W B D L$ witches' broom disease of lime, $W X$ western X-disease

'Candidatus Phytoplasma asteris' PaWB strain (PaWB) is the causal agent of paulownia witches' broom disease, an important paulownia tree disease. Once infected with PaWB, tree vigor is reduced, occasionally followed by dieback. Until 1960, more than 1 million PaWB-infected trees were found in Japan, excluding Hokkaido Prefecture 
and the Tohoku region (Ito 1960), and the disease later spread to almost every plantation in the Tohoku region (Nakamura et al. 1998). Paulownia witches' broom disease also occurs in China (Hiruki 1999), where it has affected 880,000 ha of plantations (Yue et al. 2008). 'Candidatus Phytoplasma oryzae' RYD strain (RYD) is the causal agent of rice yellow dwarf disease, a serious rice disease in many regions of Asia. Early infection with RYD results in a nearly $80 \%$ yield loss. In the 1960 s, rice yellow dwarf disease occurred in 10-50\% of rice growing areas of Japan and caused serious economic losses in many prefectures (Komori 1966; Sameshima 1967). In other cases, sweet potato witches' broom disease threatened the food supply in the Ryukyu Islands in the 1950s and 1960s (Nakamori and Maezato 1968; Shinkai 1964), and hydrangea phyllody disease remains a destructive disease in hydrangea cultivation (Kanehira et al. 1996; Sawayanagi et al. 1999; Takinami et al. 2013).

There is no effective way to control phytoplasma diseases; thus, early detection and removal of infected plants are critical to prevent the spread of disease. Until the early 1980s, phytoplasma diseases were diagnosed by transmission electron microscopic (TEM) observation because of their small size and the difficulty of culturing phytoplasmas in vitro. However, that approach requires expensive TEM equipment and time to prepare ultrathin sections of phloem tissue. In the 1980s, simple diagnostic techniques for phytoplasma diseases, such as direct fluorescence detection (DFD) (Namba et al. 1981) and DAPI staining (Hiruki and da Rocha 1986), were developed, both of which utilize florescent microscopy. The DFD method detects autofluorescence of necrotic phloem cells, and DAPI detects phytoplasmal DNA. Enzyme-linked immunosorbent assay (ELISA), the most prevalent method to diagnose viral diseases, was rarely used to detect phytoplasmal diseases in the 1980s, except for a few successful cases (Lin and Chen 1985), because it was difficult to prepare a phytoplasmaspecific antibody at that time due to difficulties in purifying phytoplasmal cells.

Around 1990, advances in molecular biology enabled direct detection of phytoplasmal DNA by DNA-DNA hybridization (Kirkpatrick et al. 1987) and the polymerase chain reaction (PCR) (Deng and Hiruki 1991). PCR amplification of the 16S rRNA genes of phytoplasmas (Lee et al. 1993; Namba et al. 1993a; Schneider et al. 1995) has become the gold standard in the diagnosis of phytoplasmal diseases. PCR has also been applied to analyze phytoplasmal localization and dynamics in planta (Nakashima and Hayashi 1995b; Sahashi et al. 1995; Wei et al. 2004b). Recently, loop-mediated isothermal amplification (LAMP) (Notomi et al. 2000) has also been used to detect several phytoplasmas and is expected to become a rapid and reliable field-diagnostic system for phytoplasma diseases
(Sugawara et al. 2012; Tomlinson et al. 2010). LAMP is more sensitive and rapid than PCR amplification and does not require DNA purification or special equipment such as a thermal cycler. The first LAMP-based detection kit for phytoplasmas has been commercially available since 2011 in Japan (http://nippongene-analysis.com/phytoplasma-fs. $\mathrm{htm})$. Application of the kit for on-site diagnosis will aid in the early control of phytoplasmal diseases.

\section{Reductive evolution of the genomes}

Biological and molecular characteristics of phytoplasmas are still quite unclear because of the difficulty in culturing them in vitro. However, in the late 1990s, several genome projects were initiated globally to explore the genomic features of phytoplasmas. At the same time, several mildpathogenicity mutants (Shiomi et al. 1998; Uehara et al. 1999) and a non-insect-transmissible mutant (Oshima et al. 2001b) were identified in Japan. Among these mutant strains, the ' $\mathrm{Ca}$. P. asteris' OY-M strain (OY-M) was thought to be suitable for whole genome analysis because the chromosome size of OY-M (ca. $870 \mathrm{kbp}$ ) was much smaller than that of the ' $\mathrm{Ca}$. P. asteris' OY-W strain (OY-W; ca. 1,000 kbp) (Oshima et al. 2001b). In parallel with the OY-M genome project, the draft genomic sequences of OY-W were obtained (Oshima et al. 2002; Miyata et al. 2002b), revealing phytoplasma codon usage (Miyata et al. 2002a), catalytic activity assays of phytoplasmal proteins (Miyata et al. 2003), and the presence of two rRNA operons (Jung et al. 2003a). In 2004, the complete genomic sequence of OY-M was determined (Oshima et al. 2004). To date, the complete genomic sequences of three other phytoplasmas have been reported (Bai et al. 2006; Tran-Nguyen et al. 2008; Kube et al. 2008).

Although phytoplasma genomes contain genes for basic cellular functions such as DNA replication, transcription, translation, and protein translocation, they lack genes for amino acid biosynthesis, fatty acid biosynthesis, the tricarboxylic acid cycle, and oxidative phosphorylation, just as in the mycoplasma genome (Razin et al. 1998). Phytoplasma genomes, however, encode even fewer metabolically functional proteins than do mycoplasma genomes, which were previously thought to have the minimum possible gene set (Mushegian and Koonin 1996). For example, phytoplasma genomes lack the pentose phosphate pathway genes and genes encoding $\mathrm{F}_{1} \mathrm{~F}_{\mathrm{o}}$-type ATP synthase. Therefore, ATP synthesis in phytoplasmas is strongly dependent on glycolysis instead of ATP synthase (Oshima et al. 2007). Interestingly, phytoplasmas harbor multiple copies of transporter-related genes not found in mycoplasmas. These genomic features suggest that phytoplasmas are highly dependent on metabolic compounds 
Table 1 Summary of insect vectors of phytoplasma diseases in Japan

\begin{tabular}{|c|c|c|c|c|}
\hline Disease name & Host plant & $\begin{array}{l}\text { Causal phytoplasma } \\
\text { species }\end{array}$ & Insect vector & References \\
\hline Anemone witches' broom & Anemone coronaria & Ca. P. asteris & Macrosteles striifrons & Namba (1996) \\
\hline Buplever yellows & Bupleurum falcatum & Ca. P. asteris & Macrosteles striifrons & Namba (1996) \\
\hline Carrot yellows & Daucus carota & $C a$. P. pruni & Ophiola flavopicta & Namba (1996) \\
\hline Celery yellows & Apium graveolens & Ca. P. pruni & Ophiola flavopicta & Namba (1996) \\
\hline China aster yellows & Callistephus chinensis & Ca. P. pruni & Ophiola flavopicta & Namba (1996) \\
\hline Cineraria witches' broom & Senecio $\times$ hybridus & $\mathrm{Ca} . \mathrm{P}$. asteris & Macrosteles striifrons & Namba (1996) \\
\hline Cosmos yellows & Cosmos bipinnatus & Ca. P. asteris & Macrosteles striifrons & Wakibe et al. (1995) \\
\hline \multirow[t]{2}{*}{$\begin{array}{l}\text { Cryptotaenia japonica witches' } \\
\text { broom }\end{array}$} & \multirow[t]{2}{*}{ Cryptotaenia japonica } & \multirow[t]{2}{*}{ Ca. P. asteris } & $\begin{array}{l}\text { Macrosteles striifrons } \\
\text { Hishimonus sellatus }\end{array}$ & $\begin{array}{l}\text { Namba (1996) } \\
\text { Nishimura et al. } \\
\text { (1998) }\end{array}$ \\
\hline & & & $\begin{array}{l}\text { Hishimonoides } \\
\text { sellatiformis }\end{array}$ & $\begin{array}{l}\text { Nishimura et al. } \\
\text { (2004) }\end{array}$ \\
\hline $\begin{array}{l}\text { Garland chrysanthemum } \\
\text { witches' broom }\end{array}$ & $\begin{array}{l}\text { Chrysanthemum coronarium var. } \\
\text { spatiosum }\end{array}$ & Ca. P. asteris & Macrosteles striifrons & $\begin{array}{l}\text { Shiomi and Sugiura } \\
\text { (1983) }\end{array}$ \\
\hline \multirow[t]{2}{*}{ Gentian witches' broom } & \multirow[t]{2}{*}{ Gentiana scabra var. buergeri } & Ca. P. pruni & Ophiola flavopicta & Namba (1996) \\
\hline & & Ca. P. asteris & Macrosteles striifrons & Tanaka et al. (2006) \\
\hline Geranium witches' broom & Pelargonium $\times$ hortorum & Ca. P. pruni & Ophiola flavopicta & Namba (1996) \\
\hline Glaucidium witches' broom & Glaucidium palmatum & Ca. P. pruni & Ophiola flavopicta & Tanaka et al. (1998) \\
\hline Hovenia witches' broom & Hovenia tomentella & Ca. P. asteris & Hishimonus sellatus & $\begin{array}{l}\text { Kusunoki et al. } \\
\text { (2002) }\end{array}$ \\
\hline Iceland poppy yellows & Papaver nudicaule & Ca. P. asteris & Macrosteles striifrons & Namba (1996) \\
\hline Jujube witches' broom & Zizyphus jujuba & Ca. P. ziziphi & Hishimonus sellatus & $\begin{array}{l}\text { Kusunoki et al. } \\
\text { (2002) }\end{array}$ \\
\hline Legume witches' broom & (plants in the family Fabaceae) & Ca. P. aurantifolia & Orosius orientalis & Namba (1996) \\
\hline Marguerite yellows & Argyranthemum frutescens & Ca. P. asteris & Macrosteles striifrons & Namba (1996) \\
\hline \multirow[t]{3}{*}{ Mulberry dwarf } & \multirow[t]{3}{*}{ Morus spp. } & \multirow[t]{3}{*}{ Ca. P. asteris } & Hishimonus sellatus & Namba (1996) \\
\hline & & & $\begin{array}{l}\text { Hishimonoides } \\
\text { sellatiformis }\end{array}$ & Namba (1996) \\
\hline & & & Tautoneura mori & Jiang et al. (2005) \\
\hline \multirow[t]{3}{*}{ Onion yellows } & \multirow[t]{3}{*}{ Allium сера } & \multirow[t]{3}{*}{ Ca. P. asteris } & Macrosteles striifrons & Namba (1996) \\
\hline & & & Hishimonus sellatus & $\begin{array}{l}\text { Nishimura et al. } \\
\text { (1998) }\end{array}$ \\
\hline & & & $\begin{array}{l}\text { Hishimonoides } \\
\text { sellatiformis }\end{array}$ & $\begin{array}{l}\text { Nishimura et al. } \\
\text { (2004) }\end{array}$ \\
\hline Potato witches' broom & Solanum tuberosum & Ca. P. pruni & Ophiola flavopicta & Namba (1996) \\
\hline Rhus yellows & Rhus javanica & Ca. P. asteris & Hishimonus sellatus & Tanaka et al. (2000) \\
\hline \multirow[t]{3}{*}{ Rice yellow dwarf } & \multirow[t]{3}{*}{ Oryza sativa } & \multirow[t]{3}{*}{ Ca. P. oryzae } & Nephotettix cincticeps & Namba (1996) \\
\hline & & & $\begin{array}{l}\text { Nephotettix } \\
\text { nigropictus }\end{array}$ & Namba (1996) \\
\hline & & & Nephotettix virescens & Namba (1996) \\
\hline Rocket larkspur witches' broom & Consolida ambigua & Ca. P. asteris & Macrosteles striifrons & Tanaka et al. (2007) \\
\hline Statice witches' broom & Limonium spp. & Ca. P. asteris & Macrosteles striifrons & Shiomi et al. (1999) \\
\hline Strawberry witches' broom & Fragaria $\times$ ananassa & Ca. P. asteris & Macrosteles striifrons & Namba (1996) \\
\hline Sweet potato witches' broom & Ipomoea batatas & Ca. P. aurantifolia & Orosius ryukyuensis & Namba (1996) \\
\hline \multirow[t]{2}{*}{ Tomato yellows } & \multirow[t]{2}{*}{ Lycopersicon esculentum } & Ca. P. pruni & Ophiola flavopicta & Namba (1996) \\
\hline & & $\mathrm{Ca} . \mathrm{P}$. asteris & Macrosteles striifrons & Kato et al. (1988) \\
\hline Tsuwabuki witches' broom & Farfugium japonicum & Ca. P. pruni & Ophiola flavopicta & Namba (1996) \\
\hline Udo dwarf & Aralia cordata & Ca. P. pruni & Ophiola flavopicta & Namba (1996) \\
\hline Water dropwort yellows & Oenanthe javanica & Ca. P. asteris & Macrosteles striifrons & $\begin{array}{l}\text { Shiomi and Sugiura } \\
\text { (1983) }\end{array}$ \\
\hline
\end{tabular}


Table 1 continued

\begin{tabular}{lllll}
\hline Disease name & Host plant & $\begin{array}{l}\text { Causal phytoplasma } \\
\text { species }\end{array}$ & Insect vector & References \\
\hline Welsh onion yellows & Allium fistulosum & Ca. P. asteris & Macrosteles striifrons & Shiomi et al. (1996) \\
White lace flower yellows & Ammi majus & Ca. P. asteris & Macrosteles striifrons & Namba (1996) \\
Chestnut yellows & Castanea spp. & Ca. P. castaneae & Unknown & - \\
Elaeocarpus yellows & $\begin{array}{l}\text { Elaeocarpus sylvestris var. } \\
\text { ellipticus }\end{array}$ & Ca. P. luffae & Unknown & - \\
Hydrangea phyllody & Hydrangea spp. & Ca. P. asteris & Unknown & - \\
Paulownia witches' broom & Paulownia tomentosa & Ca. P. japonicum & Unknown & - \\
\hline
\end{tabular}

from their hosts (Oshima et al. 2013). Phytoplasma genomes contain the sodA gene, which encodes superoxide dismutase that can inactivate reactive oxygen species (ROS) (Miura et al. 2012). Plants deploy a broad range of defenses during infection by various pathogens. The oxidative burst, which produces ROS, is one of the earliest events in the plant defense response. Since the genomes of mycoplasmas do not contain this gene, the presence of sodA may defend phytoplasmas against the unique threat of ROS released by the plant cell. Phytoplasma genomes also contain clusters of repeated gene sequences called potential mobile units (PMUs) (Bai et al. 2006), which consist of similar genes organized in a conserved order (Arashida et al. 2008a; Jomantiene and Davis 2006). A PMU in ' $C a$. P asteris' AY-WB strain (AY-WB) exists as both linear chromosomal and circular extrachromosomal elements (Toruño et al. 2010), suggesting the ability to transpose within the genome.

\section{Characteristic features of the plasmids}

In general, a phytoplasma genome consists of one chromosome and several small plasmids (Firrao et al. 2007). Phytoplasmal plasmids were cloned in the late 1980s (Davis et al. 1988; Nakashima et al. 1991) and have often been used as targets of DNA hybridization to compare phytoplasma strains (Nakashima and Hayashi 1995a). Complete nucleotide sequence analyses of the plasmids revealed that they may be products of DNA recombination between the phytoplasmal plasmids (Nishigawa et al. 2002a) and that each plasmid encodes a replication initiation protein (Rep) involved in rolling-circle replication, as well as several other unknown proteins (Nakashima and Hayashi 1997; Kuboyama et al. 1998; Nishigawa et al. 2003). Interestingly, the phytoplasmal Reps are similar to the Reps encoded by bacterial plasmids and to geminivirus (Nakashima and Hayashi 1997; Nishigawa et al. 2001) and circovirus Reps (Oshima et al. 2001a), suggestive of evolutionary relationships between phytoplasmas and viruses.
The functions of other genes in the phytoplasmal plasmids remain unknown. However, some genes are apparently related to adaptation to the insect host. For example, ' $\mathrm{Ca}$. P. asteris' OY-NIM strain (OY-NIM), a non-insect-transmissible derivative line of OY-M, lacked the ability to express the ORF3 gene encoded in plasmids (Nishigawa et al. 2002b; Ishii et al. 2009a). Sequence analysis of the plasmids over 10 years revealed that one of the plasmids was gradually lost from OY-NIM and finally disappeared during the maintenance of OY-NIM in plant tissue culture (Ishii et al. 2009b). These results suggested that the plasmid is not essential for phytoplasmal viability in a plant host, but may be a key element for adaption to an insect host.

\section{Molecular mechanisms of insect transmissibility}

Phytoplasmas are transmitted by specific insect species in a persistent manner. It is important to understand the molecular mechanisms underlying these strict pathogen-insect specificities in order to control phytoplasmal diseases. Many insect vectors involved in phytoplasma diseases have been identified in Japan (Table 1). Building on knowledge about the insect vectors, recent studies on phytoplasmal localization in nonvector insects revealed that the phytoplasmainsect specificity is determined by the ability to pass through several physical barriers, including the midgut and salivary gland (Nakajima et al. 2002, 2009).

Since phytoplasmas are endocellular parasites that lack a cell wall, their membrane proteins and secreted proteins function directly in the host cell. In many phytoplasmas, a subset of membrane proteins (usually referred to as immunodominant membrane proteins) accounts for a major portion of the total cellular membrane proteins (Kakizawa et al. 2006b). Immunodominant membrane proteins were classified into three types: immunodominant membrane protein (Imp) (Kakizawa et al. 2009), antigenic membrane protein (Amp) (Kakizawa et al. 2004), and immunodominant membrane protein A (IdpA) (Neriya et al. 2011), 


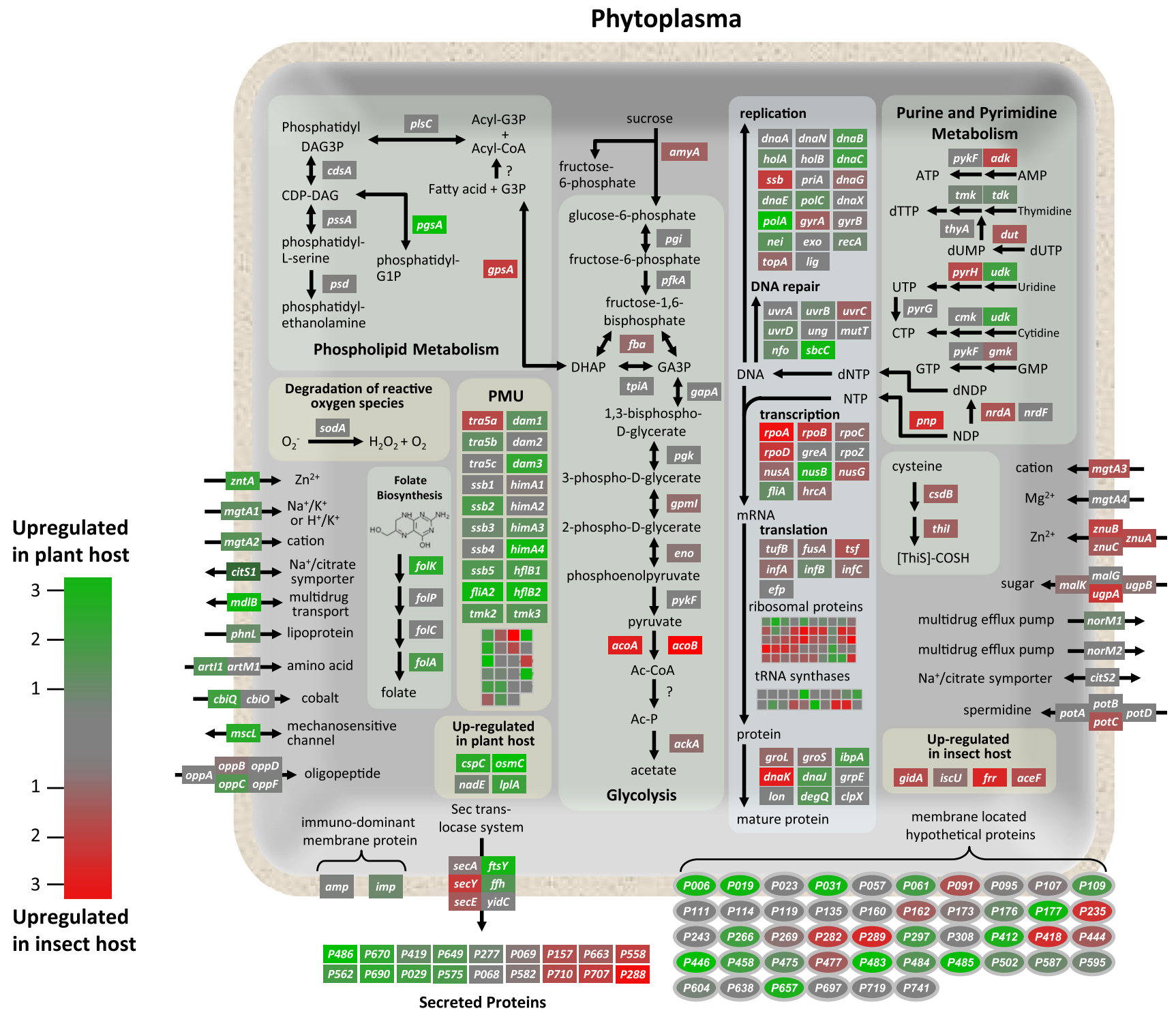

Fig. 3 Global patterns of gene regulation in phytoplasma associated with host switching between plant and insect (modified from Oshima et al. 2011). Genes upregulated in the plant host are in green; those upregulated in the insect host are in red

which are not orthologues. In both OY-W and OY-M, Amp was a major surface membrane protein (Kakizawa et al. 2009). Cloning of amp genes from several phytoplasma strains showed that Amp proteins are under positive selection, and positively selected amino acids can be found in the central hydrophilic domain (Kakizawa et al. 2006a). In addition, the Amp protein forms a complex with insect microfilaments (Suzuki et al. 2006). Interestingly, the formation of Amp-microfilament complexes was correlated with the phytoplasma-transmitting capability of leafhoppers, suggesting that the interaction between Amp and insect microfilaments may play a major role in determining the transmissibility of phytoplasmas (Suzuki et al. 2006). The interaction between Amp and actin (a component of microfilament), as well as the ATP synthase $\beta$ subunit of insect vectors, has also been observed for the CYP strain of 'Ca. P. asteris' (Galetto et al. 2011).

Moreover, a phytoplasmal microarray analysis of OY-M revealed that expression of approximately one-third of the genes is affected during host switching between plant and insect, suggesting that the phytoplasma alters its gene expression in response to its host (Fig. 3) and may use transporters, membrane proteins, secreted proteins, and metabolic enzymes in a host-specific manner (Oshima et al. 2011).

\section{Virulence factors involved in unique symptoms}

Phytoplasmas cause dramatic changes in plant development (Arashida et al. 2008b); however, the molecular 
mechanisms underlying their pathogenicity remain unclear. The phytoplasma genome lacks homologs of the type III secretion system, which are essential for the virulence of most phytopathogenic bacteria (Abramovitch et al. 2006), and for toxins produced by Pseudomonas spp., cell wall maceration enzymes of Pectobacterium spp., and the type IV secretion system of Rhizobium (Agrobacterium) spp. (Oshima et al. 2004). On the other hand, phytoplasmas have no cell walls and reside within host cells, and their secreted proteins are believed to directly function in the host plant or insect cells. The genes encoding SecA, SecY, and SecE, required for protein translocation in Escherichia coli (Economou 1999), were identified in strain OY-M of ' $\mathrm{Ca}$. P. asteris' (Kakizawa et al. 2001, 2004) and in three other phytoplasma genomes (Bai et al. 2006; Kube et al. 2008; Tran-Nguyen et al. 2008). In addition, SecA protein was expressed in plants infected with five respective phytoplasma species (Wei et al. 2004a). These results suggest that the Sec system is widely conserved among phytoplasmas.

Homologs of the virulence genes of other phytopathogenic bacteria were not identified in the phytoplasma genomes. Therefore, phytoplasmal proteins secreted via the $\mathrm{Sec}$ system are candidate virulence factors that induce morphological changes. In 2009, a secreted protein (TENGU) was identified from OY-M as the first phytoplasmal virulence factor (Hoshi et al. 2009). TENGU induces witches' broom and dwarfism, which are typical of phytoplasma infection in Nicotiana benthamiana and Arabidopsis thaliana. TENGU homologs from several phytoplasma strains induce similar symptoms (Sugawara et al. 2013). Microarray analysis of TENGU-transgenic Arabidopsis plants revealed that TENGU inhibits auxinrelated pathways, thereby affecting plant development (Fig. 4) (Hoshi et al. 2009). More recently, TENGU was found to be processed in planta into a small functional peptide, similar to the proteolytic processing of plant endogenous peptide signals (Sugawara et al. 2013). As for phyllody symptoms, a previous study has shown the involvement of the floral homeotic MADS-domain transcription factors of the floral ABCE model (floral quartet model) (Himeno et al. 2011). Recently, PHYL1 and SAP54 were found to be homologous secreted proteins that induce phyllody in floral organs of Arabidopsis thaliana (MacLean et al. 2011; Maejima et al. 2014). PHYL1 actually interacts with and degrades these MADS-domain transcription factors (Maejima et al. 2014). PHYL1 gene was genetically and functionally conserved among other phytoplasma strains and species. Therefore, PHYL1 and its homologs were designated as members of the phyllodyinducing gene family "phyllogen." SAP11, a secreted protein from AY-WB, contains eukaryotic nuclear localization signals and localizes in plant cell nuclei (Bai et al. 2009). SAP11 downregulates JA synthesis and increases

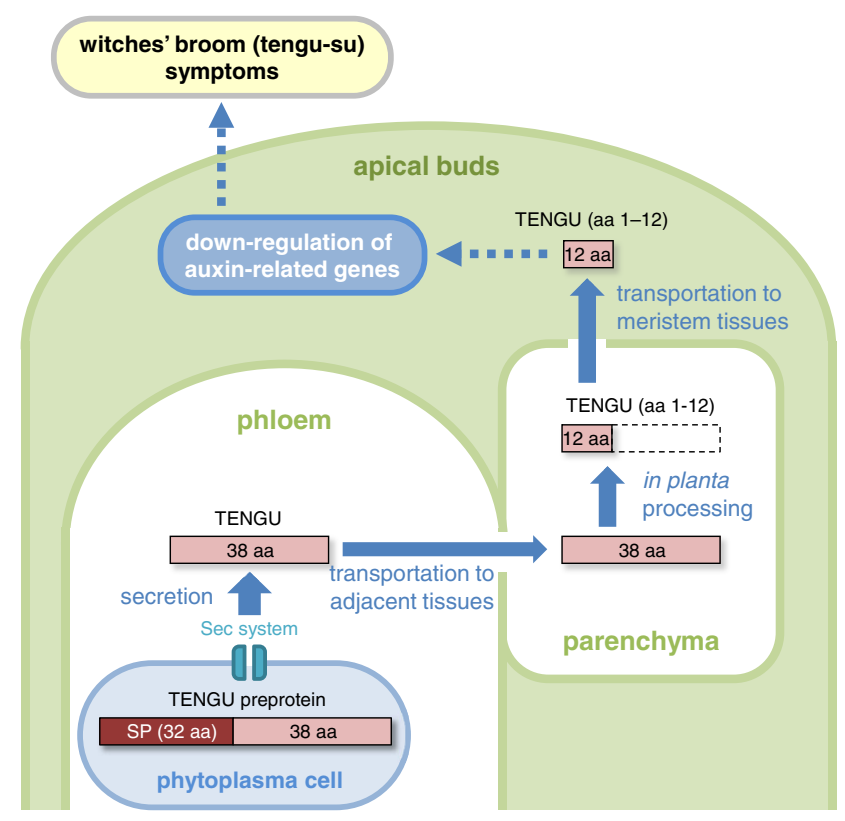

Fig. 4 Hypothetical mechanism of witches' broom (tengu-su) symptoms induced by a phytoplasmal virulence factor, TENGU. TENGU, a small peptide secreted from the phytoplasma, is translated as a 70-amino acid preprotein with a signal peptide (SP) of 32 amino acids (aa) at its $\mathrm{N}$ terminus. The C-terminal 38 aa of TENGU preprotein are secreted into plant phloem via the Sec system, a bacterial conserved protein translocation system on the cellular membrane, where the $\mathrm{N}$-terminal signal peptide is cleaved. TENGU is transported from phloem into parenchyma and apical buds. During the transportation, TENGU is proteolytically processed into the active form consisting of $\mathrm{N}$-terminus 12 aa. The active form of TENGU inhibits auxin-related pathways, resulting in induction of witches' broom (tengu-su) symptoms

the fecundity of insect vectors (Sugio et al. 2011). In addition to these secreted proteins, the consumption of plant metabolites by phytoplasmas may be associated with virulence. The duplicated glycolytic genes in OY-W are likely responsible for the severe symptoms (Oshima et al. 2007). Moreover, in the most recent study, activation of the host anthocyanin biosynthesis pathway in response to phytoplasma infection is responsible for purple top symptoms and is associated with a reduction of leaf cell death (Himeno et al. 2014). Through all these studies, the molecular mechanisms of phytoplasma symptoms are becoming clear. On the other hand, the biological significance of the unique symptoms, which is also an interesting topic, remains largely unknown, and awaits further study.

\section{Concluding remarks}

Although phytoplasmas remain the most poorly characterized phytopathogens, recent studies have identified virulence factors that induce typical phytoplasma disease 
symptoms and have characterized the unique reductive evolution of the genome. Phytoplasma-related diseases are expected to increase because the warming global climate is advantageous to the cold-sensitive vectors of the phytoplasmas. Therefore, pest control and detection of phytoplasmas are important. Further analysis of phytoplasmas at the molecular level will increase our understanding of these economically important and biologically fascinating microorganisms.

Open Access This article is distributed under the terms of the Creative Commons Attribution License which permits any use, distribution, and reproduction in any medium, provided the original author(s) and the source are credited.

\section{References}

Abramovitch RB, Anderson JC, Martin GB (2006) Bacterial elicitation and evasion of plant innate immunity. Nat Rev Mol Cell Biol 7:601-611

Anonymous (1919) Annu Rep Kochi Agric Res Inst: 62

Arashida R, Kakizawa S, Hoshi A, Ishii Y, Jung H-Y, Kagiwada S, Yamaji Y, Oshima K, Namba S (2008a) Heterogeneic dynamics of the structures of multiple gene clusters in two pathogenetically different lines originating from the same phytoplasma. DNA Cell Biol 27:209-217

Arashida R, Kakizawa S, Ishii Y, Hoshi A, Jung H-Y, Kagiwada S, Yamaji Y, Oshima K, Namba S (2008b) Cloning and characterization of the antigenic membrane protein (Amp) gene and in situ detection of Amp from malformed flowers infected with Japanese hydrangea phyllody phytoplasma. Phytopathology 98:769-775

Bai X, Zhang J, Ewing A, Miller SA, Radek A, Schevchenko DV, Tsukerman K, Walunas T, Lapidus A, Campbell JW, Hogenhout SA (2006) Living with genome instability: the adaptation of phytoplasmas to diverse environments of their insect and plant hosts. J Bacteriol 188:3682-3696

Bai X, Correa VR, Toruño TY, Ammar E-D, Kamoun S, Hogenhout SA (2009) AY-WB phytoplasma secretes a protein that targets plant cell nuclei. Mol Plant Microbe Interact 22:18-30

Brown SE, Been BO, McLaughlin WA (2006) Detection and variability of the lethal yellowing group (16Sr IV) phytoplasmas in the Cedusa sp. (Hemiptera: Auchenorrhyncha: Derbidae) in Jamaica. Ann Appl Biol 149:53-62

Davis MJ, Tsai JH, Cox RL, McDaniel LL, Harrison NA (1988) Cloning of chromosomal and extrachromosomal DNA of the mycoplasmalike organism that causes maize bushy stunt disease. Mol Plant Microbe Interact 1:295-302

Deng S, Hiruki C (1991) Amplification of 16S rRNA genes from culturable and nonculturable mollicutes. J Microbiol Methods 14:53-61

Doi Y, Teranaka M, Yora K, Asuyama H (1967) Mycoplasma- or PLT group-like microorganisms found in the phloem elements of plants infected with mulberry dwarf, potato witches' broom, aster yellows or paulownia witches' broom (in Japanese with English summary). Ann Phytopath Soc Japan 33:259-266

Economou A (1999) Following the leader: bacterial protein export through the Sec pathway. Trends Microbiol 7:315-320

Firrao G, Garcia-Chapa M, Marzachì C (2007) Phytoplasmas: genetics, diagnosis and relationships with the plant and insect host. Front Biosci 12:1353-1375

Galetto L, Bosco D, Balestrini R, Genre A, Fletcher J, Marzachì C (2011) The major antigenic membrane protein of "Candidatus
Phytoplasma asteris" selectively interacts with ATP synthase and actin of leafhopper vectors. PLoS ONE 6:e22571

Granados RR, Maramorosch K, Shikata E (1968) Mycoplasma: suspected etiologic agent of corn stunt. Proc Natl Acad Sci USA 60:841-844

Himeno M, Neriya Y, Minato N, Miura C, Sugawara K, Ishii Y, Yamaji Y, Kakizawa S, Oshima K, Namba S (2011) Unique morphological changes in plant pathogenic phytoplasmainfected petunia flowers are related to transcriptional regulation of floral homeotic genes in an organ-specific manner. Plant $\mathbf{J}$ 67:971-979

Himeno M, Kitazawa Y, Yoshida T, Maejima K, Yamaji Y, Oshima K, Namba S (2014) Purple top symptoms are associated with reduction of leaf cell death in phytoplasma-infected plants. Sci Rep 4:4111

Hiruki C (1999) Paulownia witches'-broom disease important in East Asia. Acta Hort 496:63-68

Hiruki C, da Rocha A (1986) Histochemical diagnosis of mycoplasma infections in Catharanthus roseus by means of a fluorescent DNA-binding agent, 4,6-diamidino-2-phenylindole-2 $\mathrm{HCl}$ (DAPI). Can J Plant Pathol 8:185-188

Hogenhout SA, Oshima K, Ammar E-D, Kakizawa S, Kingdom HN, Namba S (2008) Phytoplasmas: bacteria that manipulate plants and insects. Mol Plant Pathol 9:403-423

Hoshi A, Oshima K, Kakizawa S, Ishii Y, Ozeki J, Hashimoto M, Komatsu K, Kagiwada S, Yamaji Y, Namba S (2009) A unique virulence factor for proliferation and dwarfism in plants identified from a phytopathogenic bacterium. Proc Natl Acad Sci USA 106:6416-6421

Hull R, Home RW, Nayar RM (1969) Mycoplasma-like bodies associated with sandal spike disease. Nature 224:1121-1122

IRPCM (2004) 'Candidatus Phytoplasma', a taxon for the wall-less, non-helical prokaryotes that colonize plant phloem and insects. Int J Syst Evol Microbiol 54:1243-1255

Ishii Y, Kakizawa S, Hoshi A, Maejima K, Kagiwada S, Yamaji Y, Oshima K, Namba S (2009a) In the non-insect-transmissible line of onion yellows phytoplasma (OY-NIM), the plasmid-encoded transmembrane protein ORF3 lacks the major promoter region. Microbiology 155:2058-2067

Ishii Y, Oshima K, Kakizawa S, Hoshi A, Maejima K, Kagiwada S, Yamaji Y, Namba S (2009b) Process of reductive evolution during 10 years in plasmids of a non-insect-transmissible phytoplasma. Gene 446:51-57

Ishiie T, Doi Y, Yora K, Asuyama H (1967) Suppressive effects of antibiotics of tetracycline group on symptom development of mulberry dwarf disease. Ann Phytopath Soc Japan 33:267-275

Ito K (1960) Witches' broom of paulownia trees (in Japanese). Forest Pests News 9:221-225

Jiang H, Saiki T, Watanabe K, Kawakita H, Sato M (2005) Possible vector insect of mulberry dwarf phytoplasma, Tautoneura mori Matsumura. J Gen Plant Pathol 71:370-372

Jomantiene R, Davis RE (2006) Clusters of diverse genes existing as multiple, sequence-variable mosaics in a phytoplasma genome. FEMS Microbiol Lett 255:59-65

Jung H-Y, Sawayanagi T, Kakizawa S, Nishigawa H, Miyata S, Oshima K, Ugaki M, Lee J-T, Hibi T, Namba S (2002) 'Candidatus Phytoplasma castaneae', a novel phytoplasma taxon associated with chestnut witches' broom disease. Int J Syst Evol Microbiol 52:1543-1549

Jung H-Y, Miyata S, Oshima K, Kakizawa S, Nishigawa H, Wei W, Suzuki S, Ugaki M, Hibi T, Namba S (2003a) First complete nucleotide sequence and heterologous gene organization of the two rRNA operons in the phytoplasma genome. DNA Cell Biol 22:209-215

Jung H-Y, Sawayanagi T, Kakizawa S, Nishigawa H, Wei W, Oshima K, Miyata S, Ugaki M, Hibi T, Namba S (2003b) 'Candidatus 
Phytoplasma ziziphi', a novel phytoplasma taxon associated with jujube witches'-broom disease. Int $\mathrm{J}$ Syst Evol Microbiol 53:1037-1041

Jung H-Y, Sawayanagi T, Wongkaew P, Kakizawa S, Nishigawa H, Wei W, Oshima K, Miyata S, Ugaki M, Hibi T, Namba S (2003c) 'Candidatus Phytoplasma oryzae', a novel phytoplasma taxon associated with rice yellow dwarf disease. Int J Syst Evol Microbiol 53:1925-1929

Kakizawa S, Oshima K, Kuboyama T, Nishigawa H, Jung H-Y, Sawayanagi T, Tsuchizaki T, Miyata S, Ugaki M, Namba S (2001) Cloning and expression analysis of Phytoplasma protein translocation genes. Mol Plant Microbe Interact 14:1043-1050

Kakizawa S, Oshima K, Nishigawa H, Jung H-Y, Wei W, Suzuki S, Tanaka M, Miyata S, Ugaki M, Namba S (2004) Secretion of immunodominant membrane protein from onion yellows phytoplasma through the Sec protein-translocation system in Escherichia coli. Microbiology 150:135-142

Kakizawa S, Oshima K, Jung H-Y, Suzuki S, Nishigawa H, Arashida R, Miyata S, Ugaki M, Kishino H, Namba S (2006a) Positive selection acting on a surface membrane protein of the plant pathogenic phytoplasmas. J Bacteriol 188:3424-3428

Kakizawa S, Oshima K, Namba S (2006b) Diversity and functional importance of phytoplasma membrane proteins. Trends Microbiol 14:254-256

Kakizawa S, Oshima K, Ishii Y, Hoshi A, Maejima K, Jung H-Y, Yamaji Y, Namba S (2009) Cloning of immunodominant membrane protein genes of phytoplasmas and their in planta expression. FEMS Microbiol Lett 293:92-101

Kanehira T, Horikoshi N, Yamakita Y, Shinohara M (1996) Occurrence of hydrangea phyllody in Japan and detection of the causal phytoplasma (in Japanese with English summary). Ann Phytopathol Soc Jpn 62:537-540

Kato S, Shiomi T, Wakibe H, Iwanami S (1988) Tomato yellows transmitted by the leafhopper vector, Macrosteles orientalis Virbaste (in Japanese with English summary). Ann Phytopath Soc Japan 54:220-223

Kawakami T (1902) On the hexenbesen of Paulownia tomentosa (in Japanese). Shokwabo, Tokyo

Kirkpatrick BC, Stenger DC, Morris TJ, Purcell AH (1987) Cloning and detection of DNA from a nonculturable plant pathogenic mycoplasma-like organism. Science 238:197-200

Kishi K (1987) The world of loupe in plant pathology (in Japanese). Ann Phytopath Soc Japan 53:275-278

Komori N (1966) Occurrence and control of rice yellow dwarf disease in Ibaraki Prefecture (in Japanese). Plant Prot 20:285-288

Kube M, Schneider B, Kuhl H, Dandekar T, Heitmann K, Migdoll AM, Reinhardt R, Seemüller E (2008) The linear chromosome of the plant-pathogenic mycoplasma 'Candidatus Phytoplasma mali'. BMC Genom 9:306

Kuboyama T, Huang C-C, Lu X, Sawayanagi T, Kanazawa T, Kagami T, Matsuda I, Tsuchizaki T, Namba S (1998) A plasmid isolated from phytopathogenic onion yellows phytoplasma and its heterogeneity in the pathogenic phytoplasma mutant. Mol Plant Microbe Interact 11:1031-1037

Kunkel LO (1926) Studies on aster yellows. Am J Bot 13:646-705

Kuske CR, Kirkpatrick BC (1992) Phylogenetic relationships between the western aster yellows mycoplasmalike organism and other prokaryotes established by $16 \mathrm{~S}$ rRNA gene sequence. Int J Syst Bacteriol 42:226-233

Kusunoki M, Shiomi T, Kobayashi M, Okudaira T, Ohashi A, Nohira T (2002) A leafhopper (Hishimonus sellatus) transmits phylogenetically distant phytoplasmas: rhus yellows and hovenia witches' broom phytoplasma. J Gen Plant Pathol 68:147-154

Lee I-M, Hammond RW, Davis RE, Gundersen DE (1993) Universal amplification and analysis of pathogen 16S rDNA for classification and identification of mycoplasmalike organisms. Phytopathology 83:834-842

Lin CP, Chen TA (1985) Monoclonal antibodies against the aster yellows agent. Science 227:1233-1235

MacLean AM, Sugio A, Makarova OV, Findlay KC, Grieve VM, Toth R, Nicolaisen M, Hogenhout SA (2011) Phytoplasma effector SAP54 induces indeterminate leaf-like flower development in Arabidopsis plants. Plant Physiol 157:831-841

Maejima K, Iwai R, Himeno M, Komatsu K, Kitazawa Y, Fujita N, Ishikawa K, Fukuoka M, Minato N, Yamaji Y, Oshima K, Namba S (2014) Recognition of floral homeotic MADS-domain transcription factors by a phytoplasmal effector, phyllogen, induces phyllody. Plant J. doi:10.1111/tpj.12495

Miura C, Sugawara K, Neriya Y, Minato N, Keima T, Himeno M, Maejima K, Komatsu K, Yamaji Y, Oshima K, Namba S (2012) Functional characterization and gene expression profiling of superoxide dismutase from plant pathogenic phytoplasma. Gene 510:107-112

Miyata S, Furuki K, Oshima K, Sawayanagi T, Nishigawa H, Kakizawa S, Jung H-Y, Ugaki M, Namba S (2002a) Complete nucleotide sequence of the S10-spc operon of phytoplasma: gene organization and genetic code resemble those of Bacillus subtilis. DNA Cell Biol 21:527-534

Miyata S, Furuki K, Sawayanagi T, Oshima K, Kuboyama T, Tsuchizaki T, Ugaki M, Namba S (2002b) Gene arrangement and sequence of str operon of phytoplasma resemble those of Bacillus more than those of Mycoplasma. J Gen Plant Pathol 68:62-67

Miyata S, Oshima K, Kakizawa S, Nishigawa H, Jung H-Y, Kuboyama T, Ugaki M, Namba S (2003) Two different thymidylate kinase gene homologues, including one that has catalytic activity, are encoded in the onion yellows phytoplasma genome. Microbiology 149:2243-2250

Mushegian AR, Koonin EV (1996) A minimal gene set for cellular life derived by comparison of complete bacterial genomes. Proc Natl Acad Sci USA 93:10268-10273

Nakajima S, Nishimura N, Matsuda I, Shiomi T, Namba S, Tsuchizaki T (2002) Detection of mulberry dwarf and onion yellows phytoplasmas by PCR from vector insects and nonvector insects (in Japanese with English summary). Jpn J Phytopathol 68:39-42

Nakajima S, Nishimura N, Jung H-Y, Kakizawa S, Fujisawa I, Namba S, Tsuchizaki T (2009) Movement of onion yellows phytoplasma and Cryptotaenia japonica witches' broom phytoplasma in the nonvector insect Nephotettix cincticeps (in Japanese with English summary). Jpn J Phtopathol 75:29-34

Nakamori K, Maezato T (1968) Control of sweet potato witches' broom disease in Okinawa (in Japanese). Plant Prot 22:19-24

Nakamura H, Ohgake S, Sahashi N, Yoshioka N, Kubono T, Takahashi T (1998) Seasonal variation of paulownia witches'broom phytoplasma in paulownia trees and distribution of the disease in the Tohoku district of Japan. J Forest Res 3:39-42

Nakashima K, Hayashi T (1995a) Extrachromosomal DNAs of rice yellow dwarf and sugarcane white leaf phytoplasmas. Ann Phytopathol Soc Jpn 61:456-462

Nakashima K, Hayashi T (1995b) Multiplication and distribution of rice yellow dwarf phytoplasma in infected tissues of rice and green rice leafhopper Nephotettix cincticeps. Ann Phytopathol Soc Jpn 61:451-455

Nakashima K, Hayashi T (1997) Sequence analysis of extrachromosomal DNA of sugarcane white leaf phytoplasma. Ann Phytopathol Soc Jpn 63:21-25

Nakashima K, Kato S, Iwanami S, Murata N (1991) Cloning and detection of chromosomal and extrachromosomal DNA from mycoplasmalike organisms that cause yellow dwarf disease of rice. Appl Environ Microbiol 57:3570-3575 
Namba S (1996) Taxonomy of phytoplasmas (in Japanese). Plant Prot 50:152-156

Namba S, Yamashita S, Doi Y, Yora K (1981) Direct fluorescence detection method (DFD method) for diagnosing yellow-type virus diseases and mycoplasma diseases of plants (in Japanese with English summary). Ann Phytopath Soc Japan 47:258-263

Namba S, Kato S, Iwanami S, Oyaizu H, Shiozawa H, Tsuchizaki T (1993a) Detection and differentiation of plant-pathogenic mycoplasmalike organisms using polymerase chain reaction. Phytopathology 83:786-791

Namba S, Oyaizu H, Kato S, Iwanami S, Tsuchizaki T (1993b) Phylogenetic diversity of phytopathogenic mycoplasmalike organisms. Int J Syst Bacteriol 43:461-467

Neriya Y, Sugawara K, Maejima K, Hashimoto M, Komatsu K, Minato N, Miura C, Kakizawa S, Yamaji Y, Oshima K, Namba S (2011) Cloning, expression analysis, and sequence diversity of genes encoding two different immunodominant membrane proteins in poinsettia branch-inducing phytoplasma (PoiBI). FEMS Microbiol Lett 324:38-47

Nishigawa H, Miyata S, Oshima K, Sawayanagi T, Komoto A, Kuboyama T, Matsuda I, Tsuchizaki T, Namba S (2001) In planta expression of a protein encoded by the extrachromosomal DNA of a phytoplasma and related to geminivirus replication proteins. Microbiology 147:507-513

Nishigawa H, Oshima K, Kakizawa S, Jung H-Y, Kuboyama T, Miyata S, Ugaki M, Namba S (2002a) Evidence of intermolecular recombination between extrachromosomal DNAs in phytoplasma: a trigger for the biological diversity of phytoplasma? Microbiology 148:1389-1396

Nishigawa H, Oshima K, Kakizawa S, Jung H-Y, Kuboyama T, Miyata S, Ugaki M, Namba S (2002b) A plasmid from a noninsect-transmissible line of a phytoplasma lacks two open reading frames that exist in the plasmid from the wild-type line. Gene 298:195-201

Nishigawa H, Oshima K, Miyata S, Ugaki M, Namba S (2003) Complete set of extrachromosomal DNAs from three pathogenic lines of onion yellows phytoplasma and use of PCR to differentiate each line. J Gen Plant Pathol 69:194-198

Nishimura N, Nakajima S, Sawayanagi T, Namba S, Shiomi T, Matsuda I, Tsuchizaki T (1998) Transmission of Cryptotaenia japonica witches' broom and onion yellows phytoplasmas by Hishimonus sellatus Uhler. Ann Phytopathol Soc Jpn 64:474-477

Nishimura N, Nakajima S, Kawakita H, Sato M, Namba S, Fujisawa I, Tsuchizaki T (2004) Transmission of Cryptotaenia japonica witches' broom and onion yellows by Hishimonoides sellatiformis (in Japanese with English summary). Jpn J Phytopathol 70:22-25

Notomi T, Okayama H, Masubuchi H, Yonekawa T, Watanabe K, Amino N, Hase T (2000) Loop-mediated isothermal amplification of DNA. Nucleic Acids Res 28:e63

Okuda S (1972) Phytoplasmal diseases in Japan (in Japanese). Plant Prot 26:180-183

Oshima K, Kakizawa S, Nishigawa H, Kuboyama T, Miyata S, Ugaki M, Namba S (2001a) A plasmid of phytoplasma encodes a unique replication protein having both plasmid- and virus-like domains: clue to viral ancestry or result of virus/plasmid recombination? Virology 285:270-277

Oshima K, Shiomi T, Kuboyama T, Sawayanagi T, Nishigawa H, Kakizawa S, Miyata S, Ugaki M, Namba S (2001b) Isolation and characterization of derivative lines of the onion yellows phytoplasma that do not cause stunting or phloem hyperplasia. Phytopathology 91:1024-1029

Oshima K, Miyata S, Sawayanagi T, Kakizawa S, Nishigawa H, Jung H-Y, Furuki K, Yanazaki M, Suzuki S, Wei W, Kuboyama T, Ugaki M, Namba S (2002) Minimal set of metabolic pathways suggested from the genome of onion yellows phytoplasma. J Gen Plant Pathol 68:225-236

Oshima K, Kakizawa S, Nishigawa H, Jung H-Y, Wei W, Suzuki S, Arashida R, Nakata D, Miyata S, Ugaki M, Namba S (2004) Reductive evolution suggested from the complete genome sequence of a plant-pathogenic phytoplasma. Nat Genet 36:27-29

Oshima K, Kakizawa S, Arashida R, Ishii Y, Hoshi A, Hayashi Y, Kagiwada S, Namba S (2007) Presence of two glycolytic gene clusters in a severe pathogenic line of Candidatus Phytoplasma asteris. Mol Plant Pathol 8:481-489

Oshima K, Ishii Y, Kakizawa S, Sugawara K, Neriya Y, Himeno M, Minato N, Miura C, Shiraishi T, Yamaji Y, Namba S (2011) Dramatic transcriptional changes in an intracellular parasite enable host switching between plant and insect. PLoS ONE 6:e23242

Oshima K, Maejima K, Namba S (2013) Genomic and evolutionary aspects of phytoplasmas. Front Microbiol 4:230

PSJ NIAS (ed) (2012) Common names of plant diseases in Japan, 2nd edn (in Japanese). Phase out, Aichi

Razin S, Yogev D, Naot Y (1998) Molecular biology and pathogenicity of mycoplasmas. Microbiol Mol Biol Rev 62:1094-1156

Sahashi N, Nakamura H, Yoshikawa N, Kubono T, Shoji T, Takahashi $\mathrm{T}$ (1995) Distribution and seasonal variation in detection of phytoplasma in bark phloem tissues of single paulownia trees infected with witches' broom. Ann Phytopathol Soc Jpn 61:481-484

Saitou N, Nei M (1987) The neighbor-joining method: a new method for reconstructing phylogenetic trees. Mol Biol Evol 4:406-425

Sameshima T (1967) Occurrence and control of rice yellow dwarf disease in Miyazaki Prefecture (in Japanese). Plant Prot 21:47-50

Sawayanagi T, Horikoshi N, Kanehira T, Shinohara M, Bertaccini A, Cousin M-T, Hiruki C, Namba S (1999) 'Candidatus Phytoplasma japonicum', a new phytoplasma taxon associated with Japanese hydrangea phyllody. Int J Syst Bacteriol 49:1275-1285

Schneider B, Seemüller E, Smart CD, Kirkpatrick BC (1995) Phylogenetic classification of plant pathogenic mycoplasma-like organisms or phytoplasmas. In: Razin S, Tully JG (eds) Molecular and diagnostic procedures in mycoplasmology. Academic Press, San Diego, pp 369-380

Shinkai A (1964) Transmission of sweet potato witches' broom disease by Orosius ryukyuensis (in Japanese). Plant Prot 18:259-262

Shiomi T, Sugiura M (1983) Water dropwort yellows and chrysanthemum witches' broom occurred in Ishikawa Prefecture (in Japanese with English summary). Ann Phytopath Soc Japan 49:367-370

Shiomi T, Tanaka M, Wakiya H, Zenbayashi R (1996) Occurrence of welsh onion yellows (in Japanese with English summary). Ann Phytopathol Soc Jpn 62:258-260

Shiomi T, Tanaka M, Sawayanagi T, Yamamoto S, Tsuchizaki T, Namba S (1998) A symptomatic mutant of onion yellows phytoplasma derived from a greenhouse-maintained isolate (in Japanese with English summary). Ann Phytopathol Soc Jpn 64:501-505

Shiomi T, Tanaka M, Uematsu S, Wakibe H, Nakamura H (1999) Statice witches' broom, a Macrosteles striifrons-borne phytoplasma disease (in Japanese with English summary). Ann Phytopathol Soc Jpn 65:87-90

Shirai M (1890) The cause of mulberry dwarf disease (in Japanese). Jpn Silk Culturist 32:1-2

Strauss E (2009) Phytoplasma research begins to bloom. Science 325:388-390

Sugawara K, Himeno M, Keima T, Kitazawa Y, Maejima K, Oshima K, Namba S (2012) Rapid and reliable detection of phytoplasma 
by loop-mediated isothermal amplification targeting a housekeeping gene. J Gen Plant Pathol 78:389-397

Sugawara K, Honma Y, Komatsu K, Himeno M, Oshima K, Namba S (2013) The alteration of plant morphology by small peptides released from the proteolytic processing of the bacterial peptide TENGU. Plant Physiol 162:2005-2014

Sugio A, Kingdom HN, MacLean AM, Grieve VM, Hogenhout SA (2011) Phytoplasma protein effector SAP11 enhances insect vector reproduction by manipulating plant development and defense hormone biosynthesis. Proc Natl Acad Sci USA 108:E1254-E1263

Suzuki S, Oshima K, Kakizawa S, Arashida R, Jung H-Y, Yamaji Y, Nishigawa H, Ugaki M, Namba S (2006) Interaction between the membrane protein of a pathogen and insect microfilament complex determines insect-vector specificity. Proc Natl Acad Sci USA 103:4252-4257

Takinami Y, Maejima K, Takahashi A, Keima T, Shiraishi T, Okano Y, Komatsu K, Oshima K, Namba S (2013) First report of 'Candidatus Phytoplasma asteris' infecting hydrangea showing phyllody in Japan. J Gen Plant Pathol 79:209-213

Tanaka M, Shiomi T, Tairako K, Uehara T, Matsuda I (1998) Occurrence of glaucidium witches' broom (in Japanese with English summary). Ann Phytopathol Soc Jpn 64:205-207

Tanaka M, Osada S, Matsuda I (2000) Transmission of rhus (Rhus javanica L.) yellows by Hishimonus sellatus and host range of the causal phytoplasma. J Gen Plant Pathol 66:323-326

Tanaka M, Kodama K, Chiba K, Iwadate Y, Usugi T (2006) Occurrence of gentian witches' broom caused by 'Candidatus Phytoplasma asteris' (in Japanese with English summary). Jpn J Phytopathol 72:191-194

Tanaka M, Tanina K, Kasuyama S, Usugi T (2007) Occurrence of rocket larkspur witches' broom caused by "Candidatus Phytoplasma asteris" in Japan. J Gen Plant Pathol 73:286-289
Tomlinson JA, Boonham N, Dickinson M (2010) Development and evaluation of a one-hour DNA extraction and loop-mediated isothermal amplification assay for rapid detection of phytoplasmas. Plant Pathol 59:465-471

Toruño TY, Musić MS, Simi S, Nicolaisen M, Hogenhout SA (2010) Phytoplasma PMU1 exists as linear chromosomal and circular extrachromosomal elements and has enhanced expression in insect vectors compared with plant hosts. Mol Microbiol 77:1406-1415

Tran-Nguyen LTT, Kube M, Schneider B, Reinhardt R, Gibb KS (2008) Comparative genome analysis of "Candidatus Phytoplasma australiense" (subgroup tuf-Australia I; rp-A) and " $C a$. Phytoplasma asteris" strains OY-M and AY-WB. J Bacteriol 190:3979-3991

Uehara T, Tanaka M, Shiomi T, Namba S, Tsuchizaki T, Matsuda I (1999) Histopathological studies on two symptom types of phytoplasma associated with lettuce yellows. Ann Phytopathol Soc Jpn 65:465-469

Wakibe H, Shiomi T, Tanaka M (1995) Cosmos yellows disease transmitted by Macrosteles striifrons in Saga Prefecture (in Japanese with English summary). Proc Assoc Plant Prot Kyushu 41:51-54

Wei W, Kakizawa S, Jung H-Y, Suzuki S, Tanaka M, Nishigawa H, Miyata S, Oshima K, Ugaki M, Hibi T, Namba S (2004a) An antibody against the SecA membrane protein of one phytoplasma reacts with those of phylogenetically different phytoplasmas. Phytopathology 94:683-686

Wei W, Kakizawa S, Suzuki S, Jung H-Y, Nishigawa H, Miyata S, Oshima K, Ugaki M, Hibi T, Namba S (2004b) In planta dynamic analysis of onion yellows phytoplasma using localized inoculation by insect transmission. Phytopathology 94:244-250

Yue HN, Wu YF, Shi YZ, Wu KK, Li YR (2008) First report of paulownia witches'-broom phytoplasma in China. Plant Dis 92:1134 